\title{
Analisis Kebutuhan Bandwidth Pada Pemanfaatan Web Streaming Justin.tv Sebagai Media E-Learning Dengan Menggunakan Wirecast Dan Desktop Presenter
}

\author{
Muhamad Ubaidilah ${ }^{1}$, Adnan Purwanto ${ }^{2}$, Wahyu Pamungkas ${ }^{3}$ \\ ${ }^{1,2,3}$ Program Studi D3 Teknik Telekomunikasi Sekolah Tinggi Teknologi Telematika Telkom Purwokerto \\ 1d309043_ubaidilah@yahoo.co.id, ${ }^{2}$ adnan@st3telkom.ac.id, ${ }^{3}$ wahyu@ st3telkom.ac.id
}

\begin{abstract}
Abstrak - Perkembangan teknologi informasi begitu cepat seperti sekarang telah banyak mengubah sudut pandang banyak orang, antara lain sudut pandang orang untuk mengubah dunia pendidikan menjadi lebih baik. Salah satu contohnya pembelajaran berbasis Information and Communication Technologies (ICT) yaitu pembelajaran menggunakan video streaming. Dengan instalasi software open source Wirecast dan Desktop presenter digunakan untuk membuat video pembelajaran Streaming, disiarkan secara real time melalui media broadcast justin.tv (internet TV Channel), diharapkan dapat lebih mendukung konsep pembelajaran kapan dan dimana saja. Masalah terbesar dari teknologi ini adalah keterbatasan bandwidth. Bandwidth adalah parameter penting untuk melakukan streaming dalam jaringan. Sedangkan proses komunikasi menggunakan video digital ini menghabiskan resource yang cukup besar. Sehingga penggunaan wireshark di sini sangat diperlukan untuk menganalisis bandwidth pada paket yang diterima oleh client. Dari hasil pengukuran video dengan standar H.264 resolusi $(720$ x 540), dengan rata-rata 20 menit dalam pengambilan sampel, sebanyak 30 pengujian sampel streaming video menggunakan wireshark, diperoleh rata-rata throughput keseluruhan 0,343 Mbps, rata-rata throughput terendah 0,309 Mbps dan throughput tertinggi 0,372 Mbps. Dapat disimpulkan bahwa jika dihasilkan throughput yang lebih besar maka kualitas video streaming akan lebih baik, tetapi jika throughput dihasilkan semakin kecil maka kualitas video streaming akan menurun
\end{abstract}

Kata Kunci: Streaming, Wirecast, Bandwidth, Throughput, Wireshark

\section{PENDAHULUAN}

Perkembangan Teknologi Informasi yang begitu cepat telah banyak membuka cara pandang banyak orang. Di dunia pendidikan hal ini bisa dilihat dengan munculnya istilah seperti e-book, e-learning, cyberclass, serta pembelajaran dengan menggunakan Video Streaming. Istilah-istilah ini muncul karena peran Information and Communication Technologies (ICT) saat ini yang begitu. Salah satunya contoh program pembelajaran berbasis ICT menggunakan Streaming yang dapat dijadikan alternatif pembelajaran.

Program pembelajaran berbasis ICT menggunakan Streaming for learning dilakukan untuk mendukung pemerataan pendidikan. Hal ini perlu mendapatkan perlakuan yang khusus sebagai salah satu alternatif pengembangan pendidikan dan peningkatan proses pembelajaran. Dengan adanya pembuatan sebuah Video pembelajaran sebagai media pembelajaran Streaming Broadcasting secara live, menggunakan media Broadcast (Internet TV Channel) yang siap menyajikan materi pembelajaran dengan lebih menarik, diharapkan dapat lebih mendukung sistem pembelajaran secara terbuka dan mendukung konsep belajar kapan dan di mana pun walaupun pengajar tidak berada ditempat sekalipun.

Hanya saja pada aplikasi live Streaming, masalah terbesar yang dihadapi dari teknologi ini adalah pada keterbatasan Bandwidth sedangkan proses komunikasi dengan menggunakan digital video ini menghabiskan resource yang cukup besar. Bandwidth adalah parameter crucial untuk melakukan Streaming dalam jaringan. Semakin besar bandwidth yang tersedia, maka semakin bagus kualitas video yang ditampilkan.

Oleh sebab itu penulis bermaksud menganalisa kebutuhan Bandwidth pada pemanfaatan Web Streaming for learning yang didukung Wirecast dan Desktop presenter, di dalam membantu proses pembuatan sebuah Video pembelajaran Streaming broadcasting secara live dengan media broadcast (Internet TV Channel). Atas dasar tersebut, penulis mengangkat judul Penelitian "Analisis Kebutuhan Bandwidth Pada Pemanfaatan Web Streaming Justin.tv Sebagai Media E-Learning Dengan Menggunakan Wirecast Dan Desktop Presenter". Dengan dirancangnya E-Learning berbasis Video Streaming ini diharapkan dapat membantu pihak-pihak yang mendukung kegiatan belajar dan mengajar. Penelitian ini akan membahas tentang bagaimana membuat sebuah video pembelajaran Streaming Broadcasting secara live menggunakan media broadcast Web Streaming Justin.tv, untuk dapat dimanfaatkan sebagai media E-Learning didukung dengan menggunakan Wirecast dan Desktop presenter kemudian dilakukan pengukuran untuk melihat seberapa besar pemakaian bandwidth menggunakan software wireshark pada sisi client. Penelitian ini akan membahas bagaimana langkah-langkah 
pembuatan video pembelajaran live streaming serta analisis dari pengumpulan data dengan metode parametik menggunakan software wireshark, wireshark juga digunakan untuk menampilkan hasil pengukuran bandwidth dari hasil pengamatan waktu tertentu. Pengujian layanan yang akan dianalisa adalah parameter throughput yang mengindikasikan kualitas baik buruknya video.

Tujuan penelitian ini adalah untuk mengetahui cara membuat serta mengetahui hasil kebutuhan Bandwidth pada pembuatan sebuah Video pembelajaran Streaming Broadcasting secara live menggunakan media broadcast Web Streaming Justin.tv untuk dapat dimanfaatkan sebagai media $E$ Learning yang didukung dengan menggunakan Wirecast dan Desktop presenter.

\section{METODOLOGI}

Metodologi yang digunakan dalam penelitian ini adalah sebagai berikut:

\section{Studi literatur}

Pada studi literatur ini dilakukan proses pemilihan suatu masalah yang akan digunakan sebagai penelitian. Selanjutnya diteruskan dengan pencarian referensi sebagai landasan dan penunjang pengerjaan sekaligus sebagai pemecahan masalah yang dihadapi.

Dalam proses penyelesaian Penelitian, penulis mengumpulkan referensi dari berbagai literatur yang berkaitan dengan streaming video, Konsep dan Implementasi Streaming video menggunakan Wirecast, Desktop Presenter, E-Learning, Protokol Streaming, Standar video H.264, Konfigurasi Streaming dan Quality of Service (QoS) video yang diperlukan dalam penulisan penelitian .

\section{Instrument Penelitian}

Dalam penelitian ini memerlukan Personal Computer (PC)/Laptop, Jaringan Internet, modem up to 7,2 Mbps, Kamera Video, Lampu Halogen, Tripod, Headphone, Blue/Green Screen, Kabel Fireware, Eksternal Hardisk, Wirecast-4.1, Desktop Presenter2.0.4, Wireshark-1.10.0. (32 bit), Microsoft Office 2007 dan Web Browser.

\section{Implementasi dan Rancangan}

Pada bagian ini akan dilakukan proses konfigurasi pembuatan video Streaming menggunakan Wirecast dan Desktop presenter dilanjutkan dengan membroadcast video melalui web streaming Justin.tv, file streaming yang berupa video kemudian di-capture dari sisi client, paket file streaming yang diterima dianalisa dengan menggunakan Wireshark.

Berdasarkan implementasi rancangan yang telah dibuat maka akan dilakukan langkah-langkah sebagai berikut: a) Mengkonfigurasi jaringan agar terkoneksi ke internet.

b) Mengimplementasikan wirecast dan desktop presenter pada windows XP SP3 pada sisi PC Presenter.

c) Mengkonfigurasi broadcast video melalui justin.tv pada PC Presenter.

d) Mengkonfigurasi Wireshark untuk melihat hasil bandwidth file streaming pada sisi PC client.

\section{Pengujian Sistem}

Pengujian dilakukan dengan mengintegrasikan seluruh sistem dari PC Presenter yang akan mengolah atau membuat video pembelajaran streaming menggunakan wirecast dan desktop presenter yang di-broadcast melalui media internet TV channel (Justin.tv) sampai pada sisi client, menguji apakah streaming video dapat diterima pada sisi client, serta menganalisa kebutuhan bandwidth streaming video yang diterima pada sisi client.

\section{A. Perancangan Awal}

Dalam penelitian ini pengambilan sampel dilakukan dibeberapa sekolah didaerah tegal tepatnya di SMK Wahid Hasyim Kecamatan Talang Kabupaten Tegal, MDA Nurul Huda Kecamatan Talang - Kabupaten Tegal, Madrasatul Qur'an Kecamatan Talang - Kabupaten Tegal serta di salah satu Studio dengan nama Hana Studio yang bertempat di Jl.Projosumarto II Rt 04 Rw 01 Desa Langgen Kecamatan Talang Kabupaten Tegal. Waktu pengambilan sampel dilakukan tidak serempak dan dilaksanakan pada bulan Juni sampai September 2013 dengan rata-rata sampel adalah 20 menit.

Secara umum konfigurasi sistem dari perancangan pada pemanfaatan web streaming justin.tv sebagai media e-learning dengan menggunakan wirecast dan desktop presenter terdiri dari Kamera video, PC Presenter, jaringan internet dan client. Dari sisi PC Presenter terdiri dari Operating Sistem Windows XP SP3, wirecast dan desktop presenter sedangkan untuk sisi client terdapat Operating Sistem Windows XP (32 bit), web browser dan wireshark.

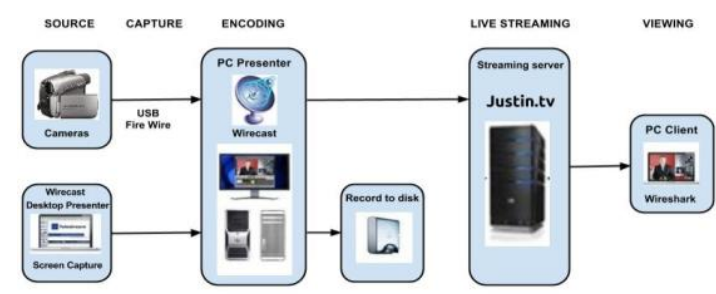

Gambar 1.Implementasi wirecast.

Pengaturan pada sisi PC Presenter

1. Instalasi Program pada sisi PC Presenter
a. Menginstal QuickTime Player
b. Menginstal Wirecast
c. Menginstal Desktop Presenter 


\section{Membuat Acount di Justin.tv}

Pembuatan account di Justin.tv dilakukan setelah proses tahap instalasi berhasil dilakukan, pembuatan account akan digunakan didalam mem-broadcast video pembelajaran secara multicast.

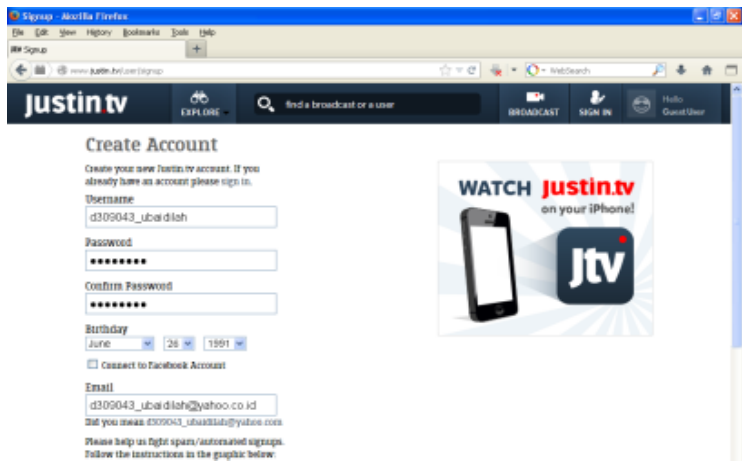

Gambar 2. Membuat Acount Justin.tv

\section{Pengaturan Software}

Pada pembuatan video pembelajaran menjadi terlihat lebih professional ada 3 software yang harus di jalankan secara bersamaan, yaitu :

a. Wirecast sebagai Controller

b. Desktop presenter sebagai media untuk menampilkan Aplikasi pembelajaran ke Wirecast.

c. Program aplikasi pembelajaran yang akan di tampilkan (Ms. PowerPoint)

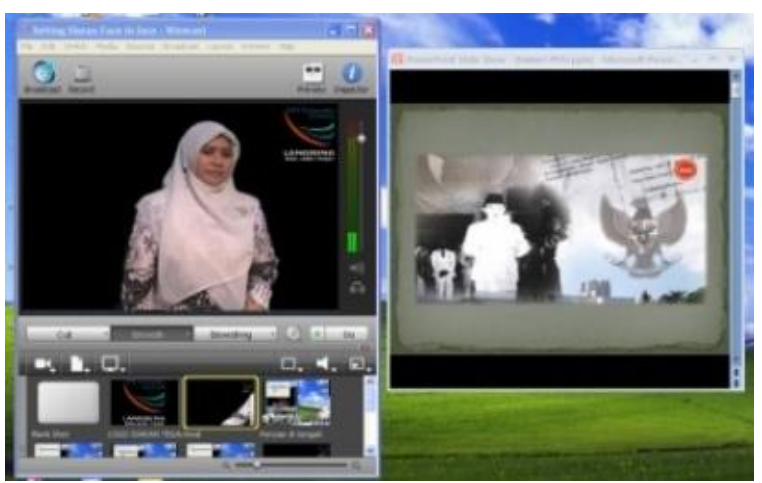

Gambar 3. Pengaturan software

Pengaturan pada sisi client

1. Instalasi program pada sisi Client

a. Menginstal Wireshark 1.10 .0

b. Menginstal WinPcap 3.1

\section{B. Pengujian Video Live Streaming}

Pengujian dilakukan menggunakan PC Presenter yang terhubungan dengan koneksi internet untuk dapat mem-broadcast video pembelajaran melalui server streaming Justin.tv, sehingga dapat diterima pada sisi client yang terhubung dalam jaringan internet yang diakses melalui web browser yang sebelumnya telah terinstal Adobe Flash Player dengan versi minimal 10.0.32 sehingga client dapat menikmati siaran video live streaming pada channel Justin.tv berupa alamat URL yang telah dibuat pada Justin.tv sebelumnya.

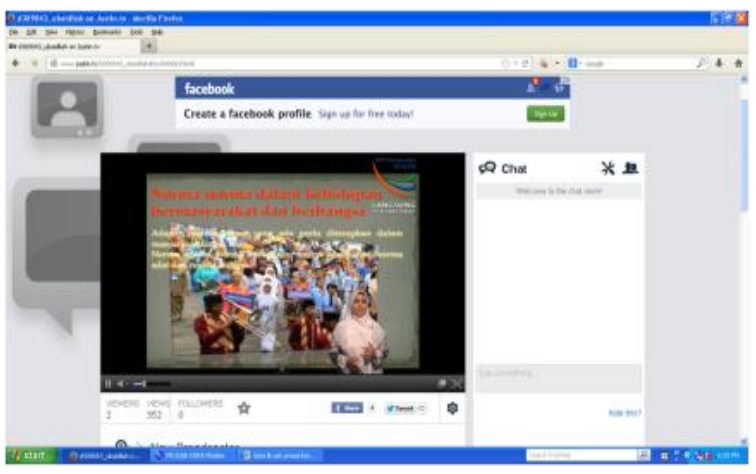

Gambar 4. Tampilan video pembelajaran yang diterima dari sisi Client

\section{Pengambilan Data}

Teknik Pengambilan data ini dilakukan dengan metode parametik pada standar video H.264 dengan resolusi $720 \times 540$ format flash video dengan melakukan sejumlah pengujian siaran live video streaming sebanyak 30 kali melalui proses pengambilan data untuk mendapatkan parameter throughput yang didukung dengan sebuah modem up to 3,6 Mbps. Sampel rata-ratanya berdurasi waktu selama 20 menit per sampel, teknik pengambilan data siaran live video streaming ini dilakukan pada sisi client dengan menggunakan wireshark.

\section{Pengamatan Throughput}

Dalam pengamatan troughput data, pengambilan data dilakukan melalui pengamatan terhadap paket video live streming yang diterima pada sisi client. Parameter tersebut merupakan jumlah Throughput rata-rata yang berhasil diamati selama durasi rata-rata 20 menit dalam proses pengujian penangkapan paket video live streaming dengan menggunakan aplikasi wireshark. Aplikasi ini cukup diminati karena kehandalannya dalam menangkap paket video live streaming.

\section{HASIL DAN PEMBAHASAN}

\section{A. Hasil Data}

Informasi yang diperoleh dari hasil perhitungan data yang di-capture oleh wireshark yaitu:

1. Jumlah paket yang di-capture

2. Durasi capture pengambilan data

3. Rata-rata besar paket

4. Kecepatan rata-rata pengiriman paket

5. Pemakaian bandwidth, rata-rata pengiriman total data per detik (rata-rata throughput).

Dari 30 kali pengujian pengambilan data sampel bandwidth yang tertangkap dengan rata-rata waktu selama 20 menit durasi pengambilan persampel.

\section{B. Analisa}

Pada hasil pengukuran throughput layanan live video streaming pada penelitian ini dengan menggunakan standar video H.264 resolusi 720x540 format flash video, proses pengambilan sampel ratarata waktu selama 20 menit per sampelnya, dengan 
metode parametik sebanyak 30 sampel pengujian live video streaming menggunakan wireshark, distreaming-kan menggunakan modem up to 3,6 Mbps, yang ditangkap pada sisi Client dengan modem up to 3,6 Mbps dengan koneksi internet yang stabil dan dengan mendapatkan sinyal penuh 3,5G (HSDPA/HSPA), diperoleh rata-rata throughput keseluruhan $0,343 \mathrm{Mbps}$, rata-rata throughput terendah 0,309 Mbps terdapat pada pengujian ke 27 dan throughput tertinggi 0,372 Mbps pada pengujian ke 12. Dapat disimpulkan bahwa jika dihasilkan throughput yang lebih besar maka kualitas video streaming akan lebih baik, tetapi jika throughput dihasilkan semakin kecil maka kualitas video streaming akan menurun. Gambar berikut diambil dari rata-rata pengujian 4 lokasi.

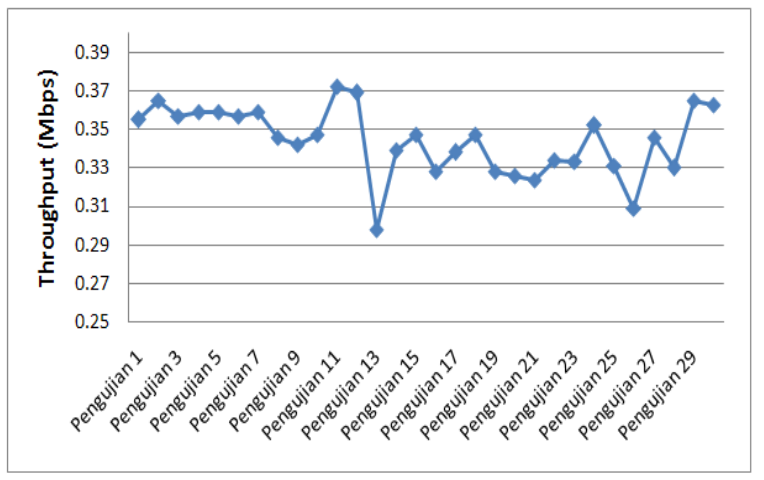

Gambar 5. Grafik nilai parameter Througput

Hal yang perlu diperhatikan adalah kebutuhan bandwidth disesuaikan dengan resolusi video yang digunakan karena hal ini akan sangat berpengaruh pada kualitas gambar yang dapat ditampilkan pada sisi client. Pada saat pengujian didapatkan data dari hasil wireshark menggunakan modem up to 3,6 Mbps dengan koneksi internet yang stabil dan dengan mendapatkan sinyal penuh 3,5G (HSDPA/HSPA) untuk menghasilkan kualitas gambar atau video dengan format flash video, resolusi 720x540 dari 30 pengujian dengan rata-rata waktu selama 20 menit, didapatkan rata-rata throughput keseluruhan pada sisi client 0,343 Mbps, video dapat ditampilkan saat koneksi internet menggunakan modem stabil namun dengan kualitas yang buruk terdapat delay frame (buffer) yang lama dan tidak dapat ditampilkan apabila koneksi internet tidak stabil, gambar atau video akan terputus-putus, atau bahkan tidak dapat tampak sama sekali. Maka dapat diketahui bandwidth yang dibutuhkan untuk dapat menghasilkan kualitas gambar, atau video dengan format flash resolusi 720x540 yang dapat diterima dengan baik pada sisi Client adalah lebih besar dari 0,343 Mbps.

Key Performance Indicator (KPI) merupakan sebuah indicator yang digunakan untuk menilai kinerja sebuah jaringan dan merupakan sebuah acuan yang harus dicapai secara keseluruhan. Dalam pemanfaatan akses streaming, KPI digunakan sebagai acuan dalam menentukan nilai parameter throughput yang harus dipenuhi untuk melakukan siaran. Dalam
30 kali penelitian yang dilakukan, jika durasi (lama waktu) rata-rata yang didapat 1258.551 maka throughput rata-rata yang diperoleh adalah 0.343 Mbps. Standar kpi untuk HSDPA adalah 256 kbps uplink dan downlink. dalam pengujian yang penulis lakukan didapat downlink dan uplink rata-rata 0.343 Mbps sehingga pengujian terhadap streaming video yang penulis lakukan telah memenuhi nilai maksimal standar kpi untuk hsdpa. Layanan media streaming pada penelitian menggunakan wirecast ini pada dasarnya berbasis web pada sisi client, yang dimaksud berbasis web di sini dikarenakan pada portal akses informasinya menggunakan protokol HTTP. Di samping itu untuk dapat membangun layanan yang interaktif diperlukan protokol RTMP. Dengan memanfaatkan protokol HTTP, protokol RTMP dapat menghantarkan paket video atau audio client-server yang digunakan pada aplikasi streaming dengan melalui RTMPT, RTMPT adalah RTMP yang melalui tunnel HTTP, data RTMP dienkapsulasi sebagai HTTP valid dengan port 80 yang secara default sama seperti HTTP. Dengan protokol RTMP inilah pengguna dapat mengakses proses streaming yang sedang berlangsung. Protokol RTMP hanya digunakan untuk aplikasi streaming dengan platform adobe flash.

Pada saat file video di stream maka akan terbentuklah sebuah buffer di komputer client dan data video tersebut akan di-download ke dalam buffer yang telah terbentuk pada mesin client. Dalam waktu sepersekian detik (jika kondisi bandwidth terpenuhi), buffer telah terisi penuh dan secara otomatis file video atau audio akan dijalankan oleh sistem. sistem akan membaca informasi dari buffer sambil tetap melakukan proses download file sehingga proses live streaming tetap berlangsung ke mesin client.

\section{KESIMPULAN}

Kesimpulan dari pengujian untuk mengetahui hasil kebutuhan Bandwidth pada Penelitian ini sebagai berikut :

a. Dari proses pembuatan video pembelajaran, dilakukan pengukuran untuk melihat seberapa besar pemakaian throughput menggunakan software wireshark pada sisi client.

b. Dari hasil pengukuran throughput layanan video live streaming pada standar video H.264 resolusi 720x540 dengan format flash video diperoleh ratarata throughput keseluruhan pada sisi client 0,343 Mbps. Video live streaming dapat ditampilkan saat koneksi internet menggunakan koneksi stabil, namun jika sebaliknya maka Video live streaming yang ditampilkan akan mempunyai kualitas yang buruk dan terjadi delay frame (buffer) yang lama sehingga gambar atau video akan terputus-putus, atau bahkan tidak dapat tampak sama sekali.

c. Bandwidth yang dibutuhkan untuk menikmati layanan Video live streaming harus lebih besar dari 0,343 Mbps. Bandwidth itu digunakan untuk 
dapat menghasilkan kualitas gambar, atau video dengan format flash resolusi 720x540 yang dapat diterima dengan baik pada sisi Client.

d. Kebutuhan bandwidth disesuaikan dengan resolusi video yang digunakan karena hal ini akan sangat berpengaruh pada kualitas gambar yang akan ditampilkan pada sisi client.

e. Rata-rata throughput terendah 0,309 Mbps terdapat pada pengujian ke 27 dan throughput tertinggi 0,372 Mbps pada pengujian ke 12. Jika throughput yang dihasilkan lebih besar, maka kualitas video streaming yang ditampilkan akan lebih baik, dan jika sebaliknya maka kualitas video streaming yang ditampilkan akan menurun (buruk).

\section{DAFTAR PUSTAKA}

[1] Purwanto, A.A. Video/TV Streaming dengan Video LAN Project. Yogyakarta : ANDI, 2005.
[2] Panji, Kirap Harmoko. Membangun Aplikasi Live Streaming Event Berbasis Web Menggunakan Protokol RTP, Bandung : Fakultas Teknik Dan Ilmu Komputer Universitas Komputer Indonesia, 2011.

[3] Aribowo, Agung. Multimedia dan Streaming dengan Syncronized Multimedia Integration Language. Jakarta : PT Elex Media Komputindo, 2003.

[4] Maruf, Zunaidi. Implementasi Aplikasi Video Conference Pada E-Pesantren Berbasis Openmeetings, Depok : Fakultas Teknik Program Studi Teknik Komputer Departemen Teknik Elektro Universitas Indonesia, 2011.

[5] Ramadha, Arif. Implementasi Darwin Streaming Server Sebagai Pendukung Jaringan IPTV. Purwokerto : Akademi Teknik Telekomunikasi Sandhy Putra, 2011.

[6] Sukra, Zener. Perancangan Motion Compensator Dan Integrasi Decoder H.264, Bandung : Program Studi Teknik Elektro Institut Teknologi Bandung, 2008. 
